\title{
Sokağa Çıkma Yasaklarının Kentlerin Hava Kalitesi Üzerindeki Etkisi, İzmir Örneği
}

\author{
Neşe Aydin ${ }^{1}$ \\ ORCID: 0000-0002-1914-3381
}

\author{
Emine Yetişkul ${ }^{2}$ \\ ORCID: 0000-0003-0829-1562
}

Öz

Bu çalışma İzmir metropoliten alanında PM10 atmosferik kirleticisinin konsantrasyonlarının Covid-19 Pandemisi önlemleri kapsamında sokağa çıkma yasaklarının uygulandığı günlerde nasıl değiştiğini tespit etmek amacıyla yapılmıştır. Bu kapsamda İmir'de bulunan sekiz adet hava kalitesi ölçüm istasyon değerleri baz alınmıştır. Sokă̆a çıkma kısıtının esnetilmeden uygulandığı 2020 yılı Nisan ayı günleri, üç ay öncesini ve üç ay sonrasını da kapsayacak şekilde 1 Ocak ile 31 Temmuz 2020 tarihleri arasındaki diğer günlerle karşılaştırılmıştır. Ayrıca 2015-

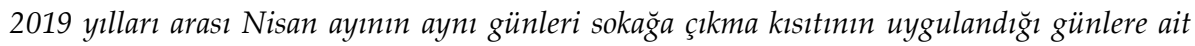
ölçümlerle karşılaştırılarak yıllık bazda hava kalitesinin nasıl değiştiği tespit edilmeye çalışılmıştır. Değerlerin analizi yapılırken 2020 yılı içerisinde alınan günlük veriler için Bağımsız Örneklem t-testi kullanılmıştır. Yıllık alınan değerlerin analizi için ise önce Friedman testi uygulanarak hangi istasyonlarda istatistiksel olarak anlamlı bir fark olduğu tespit edilmiş, daha sonra Wilcoxon testi uygulanarak hangi yıllar ile 2020 yıl ölçümleri arasında istatistiksel olarak anlamlı bir fark olduğu araştırılmıştır. Çalışmanın sonucunda, genel olarak sokă̆a çıkma kısıtınn uygulandığı günlerde hava kalitesinde PM10 konsantrasyonları açısından iyileşme olduğu tespit edilmiştir. Bu bulgular kentli olarak kent içinde günlük hareketliliğimizin, yaşadtğımız çevrenin hava kalitesini olumsuz yönde etkilediğini ortaya koymuş, kentlerimizi planlarken hava kirliliğini göz önünde bulundurmamız gerektiği ihtiyacın göstermiştir.

Anahtar Kelimeler: Covid-19 Pandemisi, Sokağa çıkma yasağı, Hava kalitesi, PM10, Kentsel planlama

\footnotetext{
${ }^{1}$ Arş. Gör., ODTÜ, E-mail: nese_aydin@yahoo.com

${ }_{2}^{2}$ Prof. Dr., ODTÜ, E-mail: yetiskul@metu.edu.tr

idealkent (c) Kent Araştırmaları Dergisi (Journal of Urban Studies)

http://idealkentdergisi.com

Geliş Tarihi Received Date: 15.02.2021 Kabul Tarihi Accepted Date: 07.09.2021
} 


\title{
The Effect of Curfews on the Air Quality of Cities, The Case of Izmir
}

\author{
Neşe Aydın ${ }^{3}$ \\ ORCID: 0000-0002-1914-3381
}

\author{
Emine Yetişkul ${ }^{4}$ \\ ORCID: 0000-0003-0829-1562
}

\begin{abstract}
This study was carried out to determine how the PM10 concentrations changed in the Izmir metropolitan area during the days when curfews were imposed because of Covid-19 Pandemic. In this context, data of eight air quality measurement stations were taken as basis. Within the scope of the study, days when curfew was strictly imposed were compared with other days, specifically between January 1, 2020 and July 31, 2020. Besides, by comparing daily measures taken between 2015-2020 on same days, it has been tried to determine how air quality has changed on an annual basis. While analyzing, Independent Sample t-test was used for daily data. For annual data, Friedman test was used to determine which stations had a statistically significant difference, and then Wilcoxon test was applied to determine in which years there was a statistically significant difference compared to 2020 measurements. All in all, it was found that there was an improvement in air quality in terms of PM10 concentrations on the days of curfew. This study revealed that our daily mobility in the city as urban dwellers negatively affect air quality of environment we live in, and showed the need to consider air pollution when planning our cities.
\end{abstract}

Keywords: Covid-19 Pandemic, Curfew, Air quality, PM10, Urban planning

\footnotetext{
${ }^{3}$ R. A., METU, E-mail: nese_aydin@yahoo.com

${ }^{4}$ Prof. Dr., METU, E-mail: yetiskul@metu.edu.tr

idealkent @ Kent Araştırmaları Dergisi (Journal of Urban Studies) 


\section{Giriş}

Mevcut araştırmalar kentlerdeki trafiğin, nüfus ve yapı yoğunluğunun, yolların sürekliliğinin, sanayi varlığının, ısınma için kentlerde kullanılan yakıtın vb. hava kalitesi üzerinde önemli etkileri olduğunu göstermektedir (Bereitschaft ve Debbage, 2013; Rydell ve Schwarz, 1968; Voorhees ve Ryckman, 1973). Pandemi dönemindeki sokağa çıkma kısıtlamaları nedeniyle, dünya genelinde, kentlerdeki insan hareketliliğinin azalması üzerinden hava kalitesine olan olumsuz etkileri çeşitli araştırmalar kapsamında ortaya konulmuştur (Bahukhandi vd., 2020; Kumari ve Toshniwal, 2020; Singh ve Tyagi, 2021; Arora vd., 2020; Nakada ve Urban, 2020; Baysan ve Yavaş, 2020). Bu çalışma kapsamında da İzmir örneği incelenerek kentteki insan hareketliliğinin hava kalitesi üzerinde ne derece etkili olduğu ölçülmeye çalışılacak ve uluslararası karşılaştırmalara katkı sunulacaktır.

Yüzyılın en büyük salgını olan Covid-19'un Dünya Sağlık Örgütünce (DSÖ) uluslararası önemi haiz pandemi ilan edilmesinden sonra ${ }^{5}$, Covid-19'un bulaş oranını azaltmak için birçok ülkede insanların hareketlerine kısıtlama tedbirleri hayata geçirilmiştir. Türkiye'de kısıtlama getiren ülkelerden bir tanesidir. Türkiye'de ilk tespit edilen Covid-19 vakası, 11 Mart 2020'de Sağlık Bakanlığı tarafından açıklanmıştır (Sağlık Bakanlığı, 2020). Bu tarihten sonra bulaşıcı hastalığın yayılımının durdurulması ve salgının kontrolü amacıyla çeşitli önlemler benimsenmiştir. Mevcut çalışma, bu önlemlerden bir tanesi olan sokağa çıkma kısıtlamasının uygulandığı 2020 yılı Nisan ayı içindeki günlerde hava kalitesinin nasıl değiştiğini incelemektedir. Nisan (2020) ayında Türkiye'de sokağa çıkma kısıtlaması getirilen günler ve uygulandığı iller Tablo 1.'de verilmiştir. İzmir de yasağın uygulandığı illerden bir tanesidir. Sonraki dönemde sokağa çıkma kısıtlamaları zaman zaman esnetilerek devam etmiştir. Bu nedenle, çalışma kapsamında tüm ticari işyerlerinin ve birçok sanayi tesisinin kapalı olduğu, kentteki hareketliliğin en düşük seviyesine gerilediği ilk dönemdeki sokağa çıma kısıtlaması uygulanan günler ele alınmış ve karşılaştırmalar yapılmıştır.

530 Ocak 2020 (DSÖ, 2020). 
Tablo 1. Türkiye'de sokağa çıkma yasağının uygulandığı tarihler ve iller (İçişleri Bakanlığı, 2020)

\begin{tabular}{lll}
\hline Sokağa Çıkma Yasağı Tarihleri & Etkilenen iller \\
\hline 11.04 .2020 & & Büyükssehir statüsündeki 30 il ile Zonguldak ili \\
\hline 12.04 .2020 & & Büyükşehir statüsündeki 30 il ile Zonguldak ili \\
\hline 18.04 .2020 & & Büyükşehir statüsündeki 30 il ile Zonguldak ili \\
\hline 19.04 .2020 & & \\
\hline 23.04 .2020 & & \\
\hline 24.04 .2020 & & \\
\hline 25.04 .2020 & &
\end{tabular}

Sokağa çıkma kısıtlamalarının, insan yaşamı ve sağlığı üzerinde birçok olumsuz etkisine karşın doğal çevre üzerinde olumlu etkileri olduğu tespit edilmiştir (Bahukhandi vd., 2020). Kentlerde bulunan suların temizlendiği (Braga vd., 2020), hava kirliliğinin azaldığı (Kumari ve Toshniwal, 2020; Singh ve Tyagi, 2021; Arora vd., 2020; Nakada ve Urban, 2020; Baysan ve Yavaş, 2020) hem uydu görüntülerinden hem de ölçüm istasyonlarındaki değerlerden tespit edilmiştir. Bu çalışma da sokağa çıkma kısıtlamalarının esnetilmeden uygulandığı Covid-19 Pandemisinin ilk dönemindeki hava kalitesindeki değişimi ortaya çıkarmayı amaçlamıştır. İzmir'deki ölçüm istasyonlarının günlük verileri istasyon temelli karşılaştırılarak insan aktiviteleri, özellikle ulaşım ve sanayi üretimi kaynaklı hava kirliliği tespit edilerek kentsel planlama çalışmalarında hava kirliliğinin önlenmesine yönelik alınacak olan kararlara dayanak oluşturulmuştur.

\section{Literatür Taraması}

Kentlerdeki hava kalitesi, doğrudan veya dolaylı olarak iklim değişikliğine, orman yangınları gibi doğal ve trafik, sanayi veya evsel ısınma gibi antropojenik kaynaklara, atmosferik (hava akımı yönü ve şiddeti) ve meteorolojik (hava sıcaklığı, nem) değişkenlere ve bölgenin topoğrafik özelliklerine göre değişiklik göstermektedir. Buna ek olarak kentlerin büyüme hızı, mekânsal olarak gelişme yönü ve biçimi de hava kalitesini etkilemektedir (Lu ve Liu, 2015; Stone vd., 2007). Hava kirliliğine fabrika, termik santral, konut, atık sahası gibi noktasal kaynaklar sebep olabildiği gibi noktasal olmayan, hareketli (Ör. motorlu taşıt trafiği) kaynaklar da sebep olabilmektedir. Bu sebeple kent formu ve dokusu, nüfus yoğunluğu, kirletici arazi kullanımlarının konumları, trafik hacmi ve sokak süreklilikleri gibi birçok kentsel planlama bileşeni hava kalitesi açısından önemlidir (Bereitschaft ve Debbage, 2013; Weng, 2003; Zhou ve Levy, 2008). 
Ulaşım ve endüstriyel aktivitelerin faaliyet merkezi olan kentler, Ozon $\left(\mathrm{O}_{3}\right)$, Uçucu Organik Bileşikler (VOCs), Nitrojenoksitler (NOx), Karbonmonoksit (CO), Kükürtdioksit ( $\left.\mathrm{SO}_{2}\right)$, ağır metaller ve Partikül Madde 10 ve 2,5 (PM10, PM2,5) vb. çok çeşitli hava kirleticilerinin yaygın olarak rastlandığ 1 ve insan sağlığını da bu yüzden olumsuz yönde etkileyen alanlardır (Grimm vd., 2008; Hadley vd., 2018). Bu nedenle, mevcut kent dokusunda hangi alanlarda, hangi etkenlerle hava kalitesinin ne ölçüde değiştiğini, hangi kent formlarının daha az hava kirliliğine neden olduğunu saptamak şehir plancıları için hem mevcut kent dokusunu hem de yeni gelişme alanlarını planlamak adına önem arz etmektedir. Mevcut literatür düşük yoğunluklu, otomobil bağımlı, yayılarak gelişen kent formlarının ve kentsel saçaklanmanın hava kirliliğini arttırdığını, yolculuk mesafelerinin kısaldığı derişik kent formlarının ise hava kirliliğini azalttı̆ını ortaya koymuştur (McCarty ve Kaza, 2015; Cervero ve Kockelman, 1997; Frank ve Pivo, 1994).

Roudrigez vd. (2016) $\mathrm{NO}_{2}, \mathrm{SO}_{2}$ ve PM10 kirleticilerini baz alarak $249 \mathrm{Av}-$ rupa kentini ele aldıkları çalışmada; parçacıl, yüksek yapılaşmanın ve nüfus yoğunluğunun olduğu kentlerde $\mathrm{NO}_{2}, \mathrm{SO}_{2}$ ve $\mathrm{PM} 10$ konsantrasyonlarının arttığına rastlandığını tespit etmiştir. Bereitschaft ve Debbage (2013) $\mathrm{O}_{3}$, PM10, PM2,5, VOC, NOx kirleticilerini baz alarak ABD'de bulunan 86 metropoliten alanda yürüttükleri çalışmada noktasal olmayan (hareketli) kirleticilerden kaynaklanan hava kirliliği ile sokak bağlantısallığının ve kentsel saçaklanmanın ilişkili olduğunu tespit etmiştir. Clark vd. (2011) O3 ve PM2,5 kirleticilerini baz alarak ABD'de bulunan 111 kenti karşılaştırdıkları çalışmada, hava kirliliğine sebep olan değişkenler arasında en fazla istatistiksel güce sahip olanlarının nüfus yoğunluğu ile nüfusun merkeziliği (merkezi iş alanı ve çevresindeki nüfus yığılması) olduğunu tespit etmiştir.

İzmir'i konu alan hava kalitesi çalışmaları incelendiğinde; Doğan ve Kitapçoğlu (2007) 1989-2004 yılları arası kış döneminde ısınmada kullanılan yakıtın -PM10 ve $\mathrm{SO}_{2}$ kirleticilerini baz alarak- hava kalitesi üzerine olan etkisini incelemiş ve politika önerileri geliştirmiştir. Elbir vd. (2008) İzmir kent merkezindeki kimi ana arterlerde 10 gün boyunca yapılan hava kalitesi ölçümlerine dayalı olarak trafik hacmiyle kirliliğin arttığını, kış mevsimi gece saatlerinde, evsel ısınma için kullanılan yakıt nedeniyle trafik hacminin azalmasına rağmen hava kirliliğinin yüksek seviyelerde seyrettiğini bulmuştur. Yatkın ve Bayram (2007) PM2,5 ve PM10 konsantrasyonların İzmir kent merkezinde (Yeşildere Semti) ve DEÜ Tınaztepe Yerleşkesinde eş zamanlı olarak bir yıl 
boyunca gerçekleştirilen ölçümlere dayalı olarak kirletici konsantrasyonlarındaki dönemsel (yaz, kış) değişime ve meteorolojik değişkenlerin hava kalitesini nasıl değiştirdiğini araştırmış, PM10 konsantrasyonlarının Tınaztepe'de kış ayları dışında $\mathrm{AB}$ sınır değerlerini aştığını tespit etmiştir.

$\mathrm{Bu}$ araştırmaların yanı sıra pandemi döneminde uygulanan sokağa çıkma kısıtlarının hava kalitesini nasıl etkilediği üzerine de çeşitli çalışmalar yapılmıştır. Kumari ve Toshnival (2020), Hindistan'da bulunan üç kentte gerçekleştirdikleri çalışmada, bir aylık PM10, $\mathrm{PM} 2,5, \mathrm{NO}_{2}$ ve $\mathrm{SO}_{2}$ kirletici konsantrasyon verilerini karşılaştırarak sokağa çıkma kısıtlamasının uygulandığı günlerde tüm kirletici konsantrasyon değerlerinin düşmüş olduğunu tespit etmişlerdir. Hindistan'da kıyı şeridinde bulunan kentleri ele alan Singh ve Tyagi (2020), PM2,5, NOx, ve CO konsantrasyonlarının çalışma kapsamındaki her kentte sokağa çıkma yasağının uygulandığı günlerde 2019 yılındaki aynı günlere göre azalmış olduğunu göstermiştir. Nakada ve Urban (2020), Brezilya'nun Sao Paulo kentinde $\mathrm{NO}, \mathrm{NO}_{2}$ ve $\mathrm{CO}$ konsantrasyonlarını araşttrarak sokağa çıkma kısıtlamasının uygulandığı günlerde hava kalitesinin arttığını tespit etmişlerdir. Çalışma kapsamında sokağa çıma kısıtının uygulandığı günlerin verileri, hem 5 yıllık bazda aynı günlerle hem de yasağın uygulandığı günlerden 1 ay öncesi ile karşılaştırılmıştır. Son olarak Baysan ve Yavaş (2020), 79 ülkenin PM2,5 ve PM10 konsantrasyon verilerini 2019 ve 2020 yıllarının ilk beş ayını baz alarak karşılaştırmış ve 2020 yılı Şubat, Nisan, Mayıs aylarında PM2,5 ve PM10 konsantrasyonlarında 2019 ile karşılaştırınca anlamlı bir farkı istatistiksel olarak ispatlamışlardır.

İzmir örneği üzerinden geliştirilen bu çalışmada da 2020 yılı Nisan ayında sokağa çıkma kısıtlamasının uygulandığı günlerin verileri, 2015-2019 yılları arasındaki aynı günlerle ve 2020 yılı içerisinde 1 Ocak-31 Temmuz tarihleri arasındaki diğer günlerle karşılaştırılmıştır. Çalışma kapsamında her bir istasyonun verileri kendi içerisinde karşılaştırılmıştır. Bu sebeple hava kalitesini etkileyen; doğal yapı (topoğrafya, bitki örtüsü vb.) ve yapılı çevre özelliklerinin (bina kat sayısı, kentsel alan kullanımları) büyük ölçüde değişmediği ve atmosferik ve meteorolojik özelliklerin de benzer olduğu kabul edilerek özellikle insan hareketliliği ve endüstriyel üretim kaynaklı etkinin ortaya çıkarılması hedeflenmiştir. Buna ek olarak sokağa çıkma kısıtlamasının uygulandığı günlerdeki kirletici konsantrasyonları, meteorolojik değişkenler d1şında hava kalitesini etkileyen diğer faktörlerin çok değişmediği 2020 yllının ilk yedi ayını içeren dönemdeki kirletici konsantrasyonları ile test edilerek, farklılık düzeyleri araştıılmıştır. 


\section{Yöntem}

\section{Hava Kalitesi Verisi}

Çevre ve Şehircilik Bakanlığı, Hava Kalitesi İzleme Ağı, Sürekli İzleme Merkezi internet portalından bu çalışma için 1 Ocak 2020-31 Temmuz 2020 tarihleri arasındaki toplam 213 güne ait hava kalitesi verileri elde edilmiştir. ${ }^{6}$ Sokağa çıkma kısıtlamasının bazı sektörlere ve işyerlerine esnetilmeden uygulandığı 11-12, 18-19, 23-26 Nisan 2020 günlerine ait veriler karşılaştırma için kullanılmıştır. 2015-2019 yılları arasındaki aynı günlere ait toplam 48 günün ölçümleri de yine aynı portaldan temin edilmiştir. Sistemde İzmir'de 23 hava kalitesi ölçüm istasyonu bulunurken, bu istasyonlardan sadece sekizi için karşılaştırılabilir düzeyde veri paylaşılmıştır. Bu doğrultuda çalışma kapsamında Şekil 1'de yerleri verilen sekiz hava kalitesi ölçüm istasyonundan elde edilen veriler kullanılmıştır. Bu istasyonlar; Alsancak İBB, Bayraklı İBB, Bornova İBB, Çiğli İBB, Gaziemir, Güzelyalı İBB, Karşıyaka İBB, Şirinyer İBB istasyonlarıdır.

Ölçüm istasyonlarının tümünde $\mathrm{SO}_{2}$ ve PM10 kirleticilerinin ölçülmüş olup, sadece Güzelyalı İBB ve Bornova İBB istasyonlarında $\mathrm{CO}, \mathrm{NO}_{2}$ ve $\mathrm{NOx}$ kirleticilerinin de ölçümleri yapılmıştır. Bu nedenle $\mathrm{CO}, \mathrm{NO}_{2}$ ve $\mathrm{NO} x$ kirleticilerine ait ölçümler çalışma kapsamına dahil edilmemiştir. $\mathrm{SO}_{2}$ ve $\mathrm{PM10}$ kirleticilerinin ülkemiz ve $\mathrm{AB}$ üyesi ülkelerde uygulanan limit değerleri Tablo 2'de verilmiştir. Kükürtdioksit kirleticisi, fosil yakıtların yanması ile oluşurken, Partikül Madde 10 kimyasallar, orman yangınları, maden çalışmaları, doğal organik oluşumlar (polen, spor vb.) ve yine fosil yakıtların yanması dolayısı ile oluşabilmektedir (Enger ve Smith, 2000; Kemp,2004). Genel olarak, trafik emisyonları, biyokütlenin yakılması, dizel jeneratörler ve endüstriyel faaliyetler için kullanılan kömürler PM10'nun ana kaynaklarıdır (Kalaiarasan, 2018).

\footnotetext{
${ }^{6}$ https://www.havaizleme.gov.tr/
} 


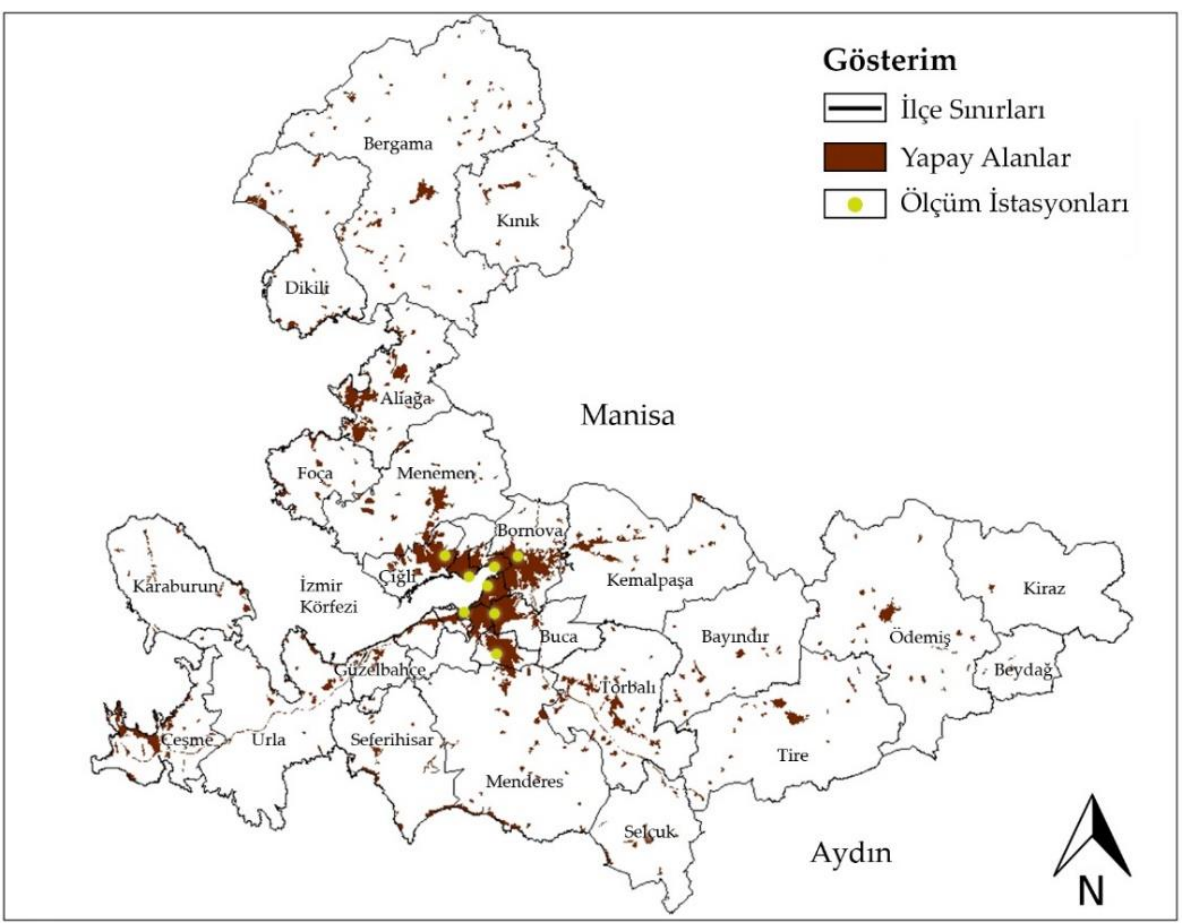

Şekil 1. Hava kalitesi ölçüm istasyonlarının konumları ${ }^{7}$

Tablo 2. İnsan sağlığı ve ekosistemin korunması için hava kalitesi sınır değerleri (Çevre ve Şehircilik Bakanlığı, 2020)

\begin{tabular}{lll}
\hline Kirletici & Ortalama & EU/TR Limit Değer \\
\hline $\mathrm{SO}^{2}$ & Günlük & $125 \mu \mathrm{g} / \mathrm{m}^{3}$ \\
\cline { 2 - 3 } & Ylllk & $20 \mu \mathrm{g} / \mathrm{m}^{3}$ \\
\hline PM10 & Günlük & $50 \mu \mathrm{g} / \mathrm{m}^{3}$ \\
\cline { 2 - 3 } & Ylllk & $40 \mu \mathrm{g} / \mathrm{m}^{3}$ \\
\hline
\end{tabular}

\footnotetext{
7 İstasyonların coğrafi konumları “http://index.havaizleme.gov.tr/Map" adresinden alınmıştır. Kentsel alanlar CORINE veri tabanındaki 1 kodlu 'Yapay Alanlar' arazi kullanımı esas alınarak hazırlanmıştır.
} 


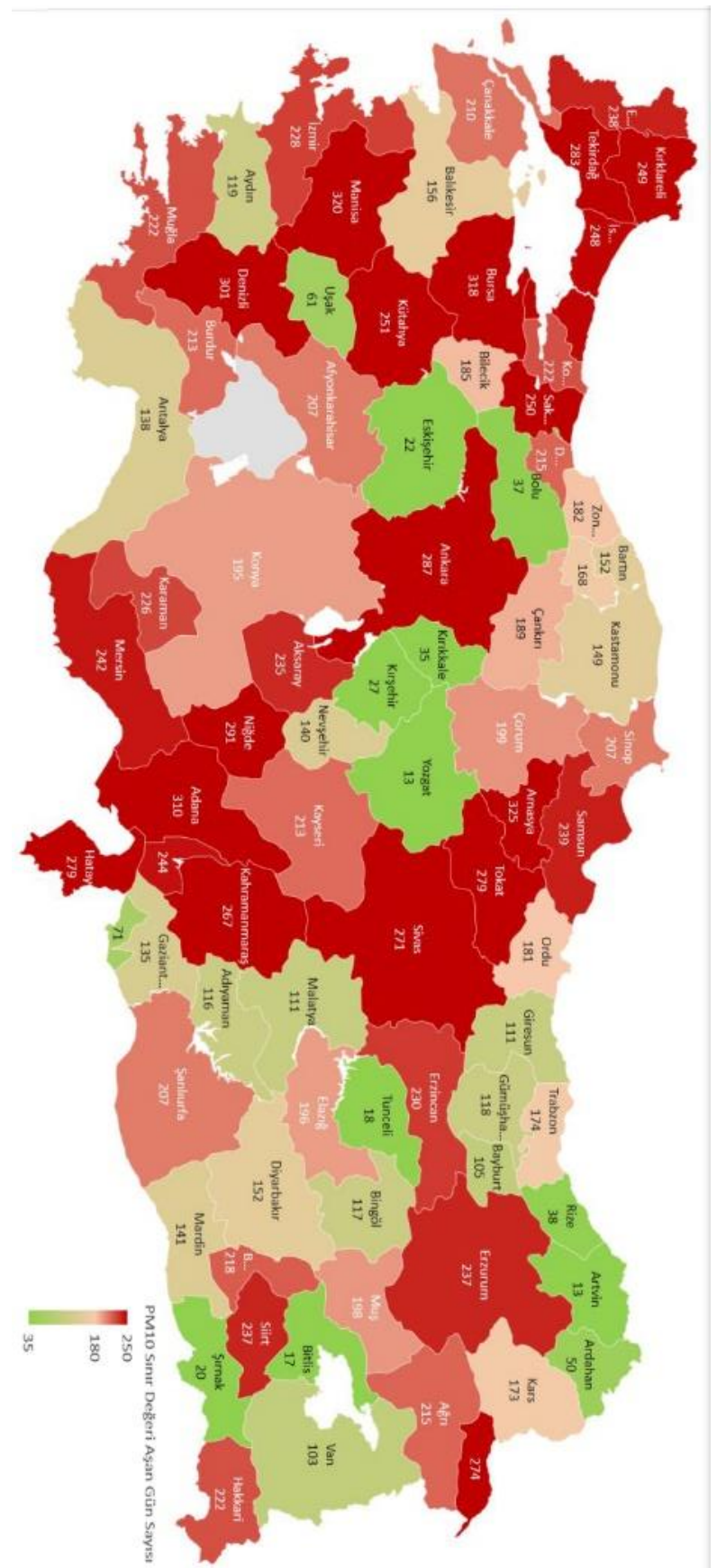

Şekil 2. İllere göre PM10 sınır değerlerini aşan gün sayıları (TMMOB Çevre Mühendisleri Odası, 2017) 
Tablo 2' de verilen limit değerler bazında sekiz istasyondan elde edilen veriler incelendiğinde, İzmir'de $\mathrm{SO}^{2}$ kirleticisinin limit değeri hiç aşmadığı görülmektedir. Yıllık düzeyde alınan günlük veriler incelendiğinde en yüksek $\mathrm{SO}_{2}$ değeri, Güzelyalı İBB istasyonunda 2018 yılının 19 Nisan günlü verisinde $52,18 \mu \mathrm{g} / \mathrm{m}^{3}$ olarak ölçülmüştür. 2020 yılı içerisinde alınan günlük veriler arasinda da en yüksek $\mathrm{SO}_{2}$ değerinin;

1-Alsancak İBB istasyonunda $77,12 \mu \mathrm{g} / \mathrm{m}^{3}$ (10 Şubat)

2-Çiğli İBB istasyonunda $56,02 \mu \mathrm{g} / \mathrm{m}^{3}$ (5 Ocak)

3-Güzelyalı IBB istasyonunda 51,12 (10 Şubat) olarak ölçüldüğü görülmüsstür.

$\mathrm{Bu}$ değerlerden de anlaşıldığ 1 üzere en yüksek $\mathrm{SO}_{2}$ kirletici değerinin bile, limit değerin \%61,7 oranında altında kaldığı gözlemlenmiştir. Partikül Madde 10 'un ise yıllık düzeyde alınan günlük ölçümleri incelendiğinde $57 \mathrm{kez}$, aylık düzeyde alınan günlük veriler incelendiğinde 238 kez limit değeri aştı̆̆1 gözlemlenmiştir. Bu nedenle Kükürtdioksit kirleticisi çalışma kapsamı dışında tutularak sadece PM10 değerine odaklanılmıştır. TMMOB Çevre Mühendisleri Odası tarafından yayınlanan 2017 Hava Kirliliği Raporuna göre İzmir'in PM10 konsantrasyonları yılda 180-250 gün arasında limit değerleri aşmaktadır.

\section{Fiziksel Yapt Verisi}

İzmir'in en önemli bölgesi, kuşkusuz, çalışmadaki bu sekiz istasyonun da yer aldığı iç Körfez veya çanak içi olarak adlandırılan kuzeyde Çiğli, Karşıyaka ve Bayraklı, doğuda Bornova, güneyde Gaziemir ve batıda Narlıdere ile sınırlı 10 ilçeyi kapsayan 'Merkez Kent'tir. İzmir 2020 yılı nüfusunun \%67'sinin yaşadığı bu bölgede özellikle kıyı boyunca kentsel kullanımların yoğunluğu (yoğun ve dağınık yerleşim alanları, endüstriyel ve ticari birimler) ve sürekliliği Şekil 3'te de görülmektedir. Yerleşim alanları 2018 yılı CORINE veri tabanı arazi kullanımı gruplamasına göre toplam 145,2 ha. bir alanı kaplarken endüstriyel ve ticari birimler ise 63,7 ha. bir alanı oluşturmaktadır. Buna ek olarak 29,0 ha. limanlar, havalimanları ve yollar ile 15,2 ha. maden ocakları, inşaat sahaları ve boşaltım/atık alanları gibi ana kirletici kentsel kullanımlar da bu merkez kentte yoğun olarak yer almaktadır.

İzmir'in hakim rüzgar yönü Güney-Güneydoğu, mevsimsel değişimlere bağlı olarak ikincil derece hakim rüzgar yönü Batı-Kuzeybatıdır. ${ }^{8}$ Bu çerçevede istasyonların bulunduğu konumlar incelendiğinde Güzelyalı ve Karşıyaka'ya körfezden ve yerleşim alanlarından rüzgar gelirken, Çiğli, Alsancak ve Bayraklı istasyonlarına yerleşim ve endüstriyel/ticari alanlardan rüzgar

\footnotetext{
${ }^{8}$ https://izmir.mgm.gov.tr/
} 
geldiği, Şirinyer, Bornova ve Gaziemir istasyonlarına da yerleşim yerlerinden ziyade tarım ve orman alanlarından da rüzgar geldiği görülmektedir.

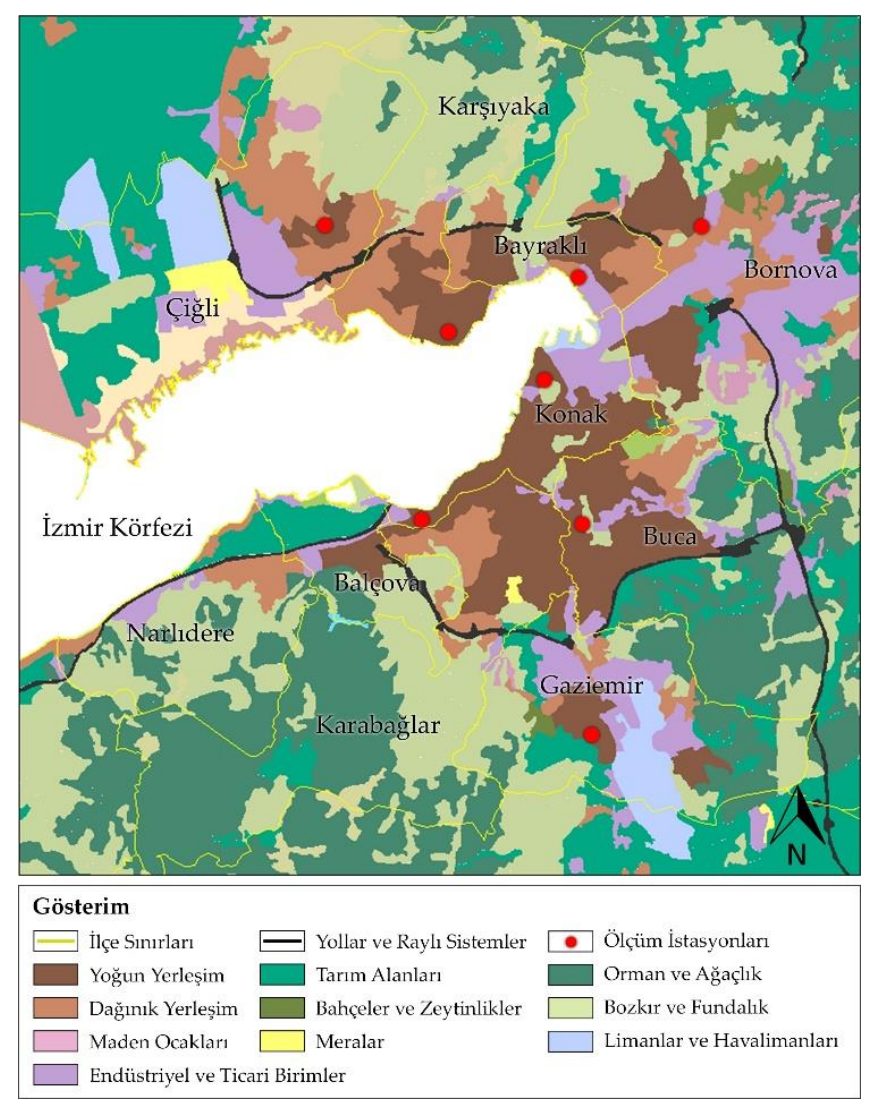

Şekil 3. İzmir' in CORINE arazi kullanım verileri

Şekil 3'te görüldüğü gibi merkez kentte kıyıdan çepere doğru özellikle orman ve doğal alanlar artsa da ölçüm istasyonları yerleşim alanında veya yerleşim alanı ile endüstriyel ve ticari birimlerin kesiştiği alanda konumlanmaktadır. Güneyde Güzelyalı ve güneydoğudaki Şirinyer İBB istasyonları yakın çevresinde konut kullanımı yoğun iken kuzeydoğuda Bayraklı, Bornova ve Alsancak İBB istasyonları yakın çevresi ise karma alan kullanımına sahiptir. Çiğli İBB istasyonu yoğun konut bölgesinde bulunmamakla beraber, istasyonun güneybatısında Organize Sanayi Bölgesi bulunmaktadır. Bu arazi kullanımının dağılımı Şekil 4'teki mahalle bazında 2020 nüfusları baz alınarak oluşturulan nüfus yoğunluğu haritasına da yansımıştır. Özellikle Konak, Karabağlar ve Buca ilçelerinin birleştiği bölgede nüfus yoğunluklarının artmakta olduğu görülmektedir. Bu yoğunluk Balçova ilçesinin iç kesiminde de devam 
etmektedir. Buca ortalama 250 kişi/ha., Konak 232 kişi/ha., Karabağlar ve Balçova 231 kişi/ha. ile merkez kentte en yüksek yoğunluğa sahip ilçelerdir. ${ }^{9}$

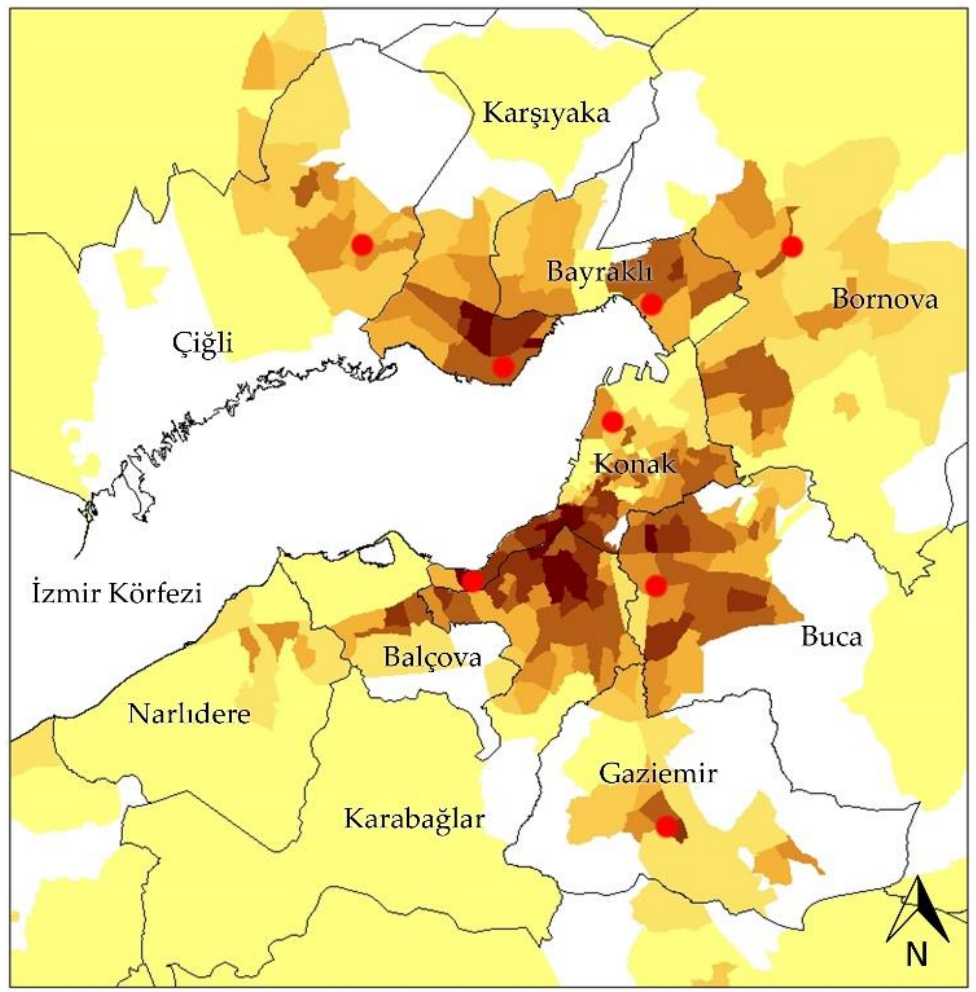

\section{Gösterim}

— İlçe Sınırları $\bullet$ Ölçüm İstasyonları

Mahalle Bazında Yoğunluk (kişi/ha)
$\square 0-13$
$\square 44-86$
$138-205$
$282-374$
$14-43$
$87-137$
$206-281$
$375-648$

Şekil 4. İzmir' in mahalle bazında nüfus yoğunluğu (TÜİK, 2021)

\footnotetext{
9 İlçe bazındaki değerler, 2018 yılı CORINE veri tabanı yerleşim (yoğun ve dağınık) alanı büyüklükleri ile 2018 yılı TÜİK veri tabanı ilçe nüfuslarından elde edilmiştir. Karabağlar ve Balçova ilçelerini 211 kişi/ha. ile Karşıyaka ve Bayraklı ilçeleri takip etmektedir. Merkez kentte ortalama yoğunluk 200 kişi/ha.'dır.
} 

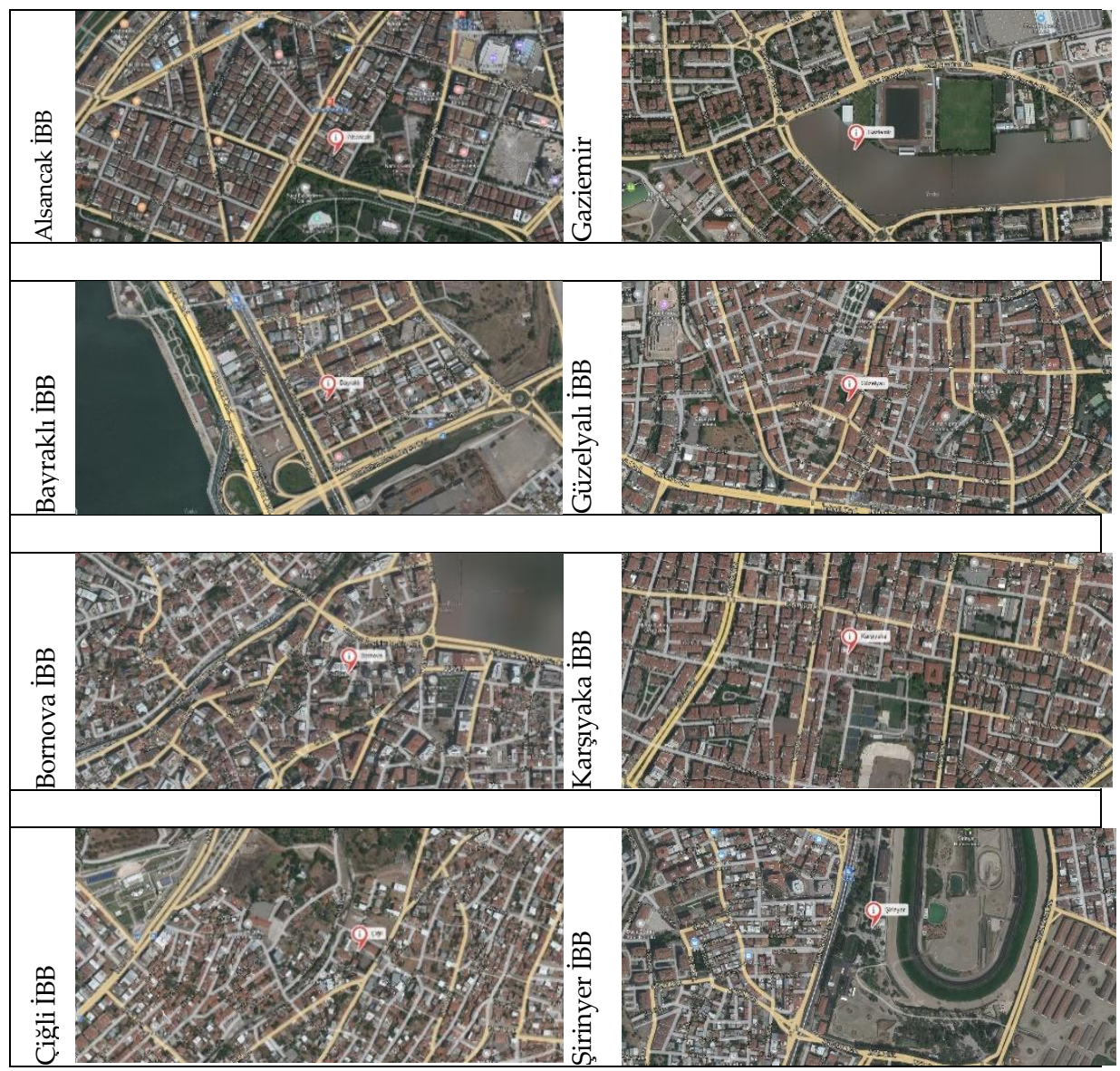

Şekil 5. İzmir hava kalitesi ölçüm istasyonlarının konumları

(Yandex Haritalar, 2021)

İstasyonların bulunduğu yapılı çevrelere odaklandığımızda Şekil 5'ten de görüldügü üzere yoğun bir kentsel doku gözlenmektedir; ancak Çiğli ve Bornova İBB istasyonları çevresinin görece boşluklu yapısı ile Güzelyalı İBB istasyonu çevresinin doluluğu dikkat çekmektedir. Özellikle nüfus yoğunluğu yüksek Konak, Karabağlar ve Balçova ilçelerinin kesişimine konumlanan Güzelyalı İBB istasyonu çevresinin yoğun konut dokusu da göz önüne alınd1ğında sokağa çıkma kısıtlamasının uygulandığı günlerde hava kalitesinde ciddi bir değişiklik gözlenmeyeceği öngörülebilir. Buna karşı trafiğin yoğun olduğu Karşıyaka, Bayraklı ve Alsancak kıyı şeridinde ise hareketliliğin en düşük seviyesine ulaştığı günlerde hava kirliliği değerlerinin fark edilir düzeyde düşmesi beklenmektedir. 


\section{Verilerin Analizi}

Verilerin analizi için IBM SPSS Statistics 26 programı kullanılmıştır. Ay bazında alınan günlük veriler analiz edilirken öncelikle veride bulunan uç değerler (Outliers) tespit edilerek analizlerden çıkarılmıştır-2020 yılı günlük verilerinde toplamda 16 uç değer tespit edilmiştir. Uç değerleri çıkarıldıktak sonra günlük verilerin dağılımının, Normal Dağılıma uygunluğu çarpıklık ve basıklık (skewness and kurtosis) istatistikleri üzerinden incelenmiştirÇarpıklık ve basıklık değerlerinin -3 ile 3 aralığında kalması durumunda verilerin Normal Dağılıma uygun olduğunu sonucuna varılmaktadır (Tabachnick ve Fidell, 2013). Yapılan ön inceleme sonucunda verilerin Normal Dağılıma uygunluk gösterdiği tespit edildiğinden, her bir istasyon için Bağımsız örneklem t-testi (Independent Sample t-test) uygulanmıştır. İlgili test bağımsız örneklemler arasında bağımlı değişkenin ortalama değerleri karşılaştırılarak gruplar arasında istatistiksel olarak anlamlı bir farkın varlığını ortaya koymak için kullanılmaktadır.

2020 yılı boyunca sokağa çıkma kısıtlamasının tam olarak uygulandığı 8 güne ait hava kalitesi verisi (PM10 ölçümleri) ile 2015-2019 yıllarının aynı günlerine ait ilgili değişkenler Friedman testinden yararlanarak karşılaştırılmıştır. Friedman testi tek yönlü ANOVA (One-way ANOVA) nın parametrik olmayan karşılığı olarak kullanılmakta olup ölçülen bağımlı değişkenin sıralı ve normal dağılım göstermediği durumlarda gruplar arasındaki farklılıkları tespit etmektedir. Dolayısıyla Friedman testi hangi istasyonlarda yıl bazında istatistiksel olarak anlamlı bir fark olduğunu saptamaya yaramaktadır. Friedman testinin akabinde 2020 yılı ile kıyaslanan hangi yıl ve 2020 yılı arasında istatistiksel olarak anlamlı bir farkın olduğunun tespit edilmesi için bağımlı değişkenin sıralı serilerden oluşması koşuluyla uygulanan Wilcoxon testinden yararlanılmıştır.

Çalışma kapsamında İzmir'de bulunan sekiz hava kalitesi ölçüm istasyonundan günlük hava kalitesi verileri alınmıştır. Bu istasyonlar; Alsancak İBB, Bayraklı İBB, Bornova İBB, Çiğli İBB, Gaziemir, Güzelyalı İBB, Karşıyaka İBB, Şirinyer İBB istasyonlarıdır. Şekil 1'de hava kalitesi ölçüm istasyonlarının yerleri görülebilmektedir. Bu istasyonlara ait 01.01.2020-31.07.2020 tarihleri arasindaki toplam 213 günlük hava kalitesi ölçüm verileri, Çevre ve Şehircilik Bakanlığı tarafından yönetilen ilgili internet portalından temin edilmiştir. ${ }^{10}$ Yine aynı internet portalından, pandemi nedeniyle sokağa çıkma kısıtlanmasının uygulandığı günlerin (11-12 Nisan, 18-19 Nisan; 23-26 Nisan 2020),

${ }^{10}$ https://www.havaizleme.gov.tr/ (Erişim: 07.12.2020) 
2015-2019 arasındaki yıllardaki (toplam 48 gün) ölçümleri de temin edilmiştir. Dolayısıyla sokağa çıkma kısıtlamasının uygulandığı günler hem 2020 yılı içerisindeki diğer günlerle, hem de 2015 'ten itibaren yıllık bazda yine aynı günler için yapılan ölçümlerle karşılaştırılmıştır.

\section{Bulgular}

\section{Yılı İçerisinde Hava Kalitesi Değģşiminin Değerlendirilmesi}

01.01.2020-31.07.2020 tarihleri arasında İzmir merkez kentte bulunan hava kalitesi ölçüm istasyonlarından alınan PM10 konsantrasyon verilerinin betimleyici istatistikleri Tablo 3'te verilmiştir. Toplamda her istasyondan, sokağa çıkma yasağının olduğu 8 gün (VAR) ve sokağa çıkma yasağının olmadığı 205 gün (YOK) olmak üzere, toplam 213 gün için veri alınmıştır. Sokağa çıkma yasaklarının uygulandığı günlerde sadece Bayraklı IBBB istasyonunda 2 gün ölçüm yapılmadığı; sokağa çıkma yasağının uygulanmadığı diğer günlerde ise Alsancak İBB istasyonunda 17, Bayraklı IBB istasyonunda 9, Bornova İBB istasyonunda 9, Çiğli İBB istasyonunda 13, Gaziemir istasyonunda 2, Karşıyaka İBB istasyonunda 14, Şirinyer İBB istasyonunda 10 gün ölçüm yapılmadığı tespit edilmiştir.

İstasyonların betimleyici istatistikleri incelendiğinde her istasyonda sokağa çıkma kısıtlamasının olduğu günler PM10 ölçüm ortalamasının diğer günler ortalamasından düşük olduğu görülmektedir. Ortanca değerleri incelendiğinde ise Bornova İBB ve Güzelyalı İBB istasyonlarının sokağa çıkma k1sttlamasının olduğu günler ölçümlerinin diğer günlerden yüksek olduğu görülmektedir. Bu durum ilgili istasyonlarda sokağa çıkma kısıtlamasının olduğu günler ve olmadığı günler arasında anlamlı bir fark tespit edilmeyeceğinin ipucunu vermektedir. Standart sapma ve varyans değerleri incelendiğinde ise tüm istasyonlarda sokağa çıkma kısıtlamasının uygulandığı günlerde PM10 konsantrasyonlarının ortalamaya yakın dağıldığı, sokağa çıkma kısıtlamasının uygulanmadığı diğer günlerde ise ortalamaya yakın değil rastgele dağıldığg görülmektedir. 
Tablo 3. İzmir'de bulunan tüm istasyonların 1 Ocak-31 Temmuz 2020 tarihleri arasındaki PM10 $\left(\mu \mathrm{g} / \mathrm{m}^{3}\right)$ ölçümlerinin betimleyici istatistikleri

\begin{tabular}{|c|c|c|c|c|c|c|c|c|c|c|}
\hline 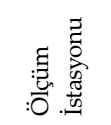 & 泀 & 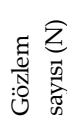 & 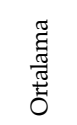 & 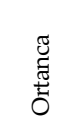 & 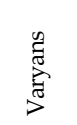 & 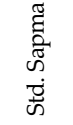 & 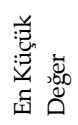 & 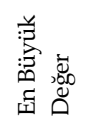 & $\frac{\text { 当 }}{\text { 离 }}$ & 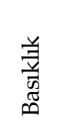 \\
\hline \multirow{4}{*}{$\begin{array}{l}\text { Alsancak } \\
\text { İBB }\end{array}$} & YOK & 188 & & & 232,07 & & & & & \\
\hline & & & 27,393 & 24,020 & 7 & 15,234 & 5,770 & 81,330 & 0,908 & 0,551 \\
\hline & VAR & 8 & & & & & & & & - \\
\hline & & & 19,041 & 17,155 & 10,901 & 3,302 & 16,430 & 24,140 & 1,040 & 0,841 \\
\hline \multirow{3}{*}{$\begin{array}{l}\text { Bayraklı } \\
\text { İBB }\end{array}$} & YOK & 196 & & & 337,14 & & & & & \\
\hline & & & 33,666 & 29,040 & 8 & 18,362 & 7,640 & 100,670 & 1,331 & 1,692 \\
\hline & VAR & 6 & 22,987 & 23,425 & 6,417 & 2,533 & 18,740 & 26,220 & $-0,774$ & 1,227 \\
\hline \multirow{3}{*}{$\begin{array}{l}\text { Ciğli } \\
\text { IBB }\end{array}$} & YOK & 192 & & & 229,06 & & & & & \\
\hline & & & 30,080 & 25,980 & 4 & 15,135 & 8,820 & 95,590 & 1,347 & 2,414 \\
\hline & VAR & 8 & 19,824 & 18,405 & 29,667 & 5,447 & 14,130 & 30,540 & 1,281 & 1,101 \\
\hline \multirow{3}{*}{$\begin{array}{l}\text { Gaziemir } \\
\text { İBB }\end{array}$} & YOK & 203 & & & 339,72 & & & & & \\
\hline & & & 43,620 & 39,950 & 7 & 18,432 & 13,170 & 120,190 & 1,309 & 2,529 \\
\hline & VAR & 8 & 36,721 & 36,600 & 30,917 & 5,560 & 30,730 & 47,320 & 0,836 & 0,697 \\
\hline \multirow{4}{*}{$\begin{array}{l}\text { Karşı- } \\
\text { yaka IBB }\end{array}$} & YOK & 191 & & & 257,46 & & & & & \\
\hline & & & 27,689 & 22,820 & 2 & 16,046 & 9,080 & 89,670 & 1,638 & 2,748 \\
\hline & VAR & 8 & & & & & & & & - \\
\hline & & & 15,823 & 14,565 & 10,431 & 3,230 & 12,670 & 20,840 & 0,612 & 1,526 \\
\hline \multirow{3}{*}{$\begin{array}{l}\text { Şirinyer } \\
\text { İBB }\end{array}$} & YOK & 195 & & & 202,77 & & & & & \\
\hline & & & 29,779 & 28,200 & 2 & 14,240 & 4,000 & 77,740 & 0,727 & 0,693 \\
\hline & VAR & 8 & 26,765 & 25,375 & 30,302 & 5,505 & 20,930 & 36,760 & 0,991 & 0,198 \\
\hline \multirow{3}{*}{$\begin{array}{l}\text { Bornova } \\
\text { İBB }\end{array}$} & YOK & 174 & & & 365,49 & & & & & \\
\hline & & & 36,344 & 32,215 & 6 & 19,118 & 9,710 & 104,420 & 1,212 & 1,573 \\
\hline & VAR & 8 & 33,659 & 33,860 & 43,686 & 6,610 & 20,550 & 43,950 & $-0,709$ & 2,503 \\
\hline \multirow{4}{*}{$\begin{array}{l}\text { Güzelyalı } \\
\text { IBBB }\end{array}$} & YOK & 196 & & & 362,55 & & & & & \\
\hline & & & 35,627 & 29,830 & 0 & 19,041 & 8,480 & 92,760 & 1,191 & 0,813 \\
\hline & VAR & 8 & & & & & & & & - \\
\hline & & & 33,819 & 33,835 & 70,421 & 8,392 & 23,240 & 47,680 & 0,431 & 0,398 \\
\hline
\end{tabular}

$\underline{\text { Tablo 4. Bağımsız Örneklem t-testi Sonuçları }\left(\mathrm{H}_{0}: \mu_{P M 10}^{Y O K}=\mu_{P M 10}^{V A R} \mathrm{H}_{1}: \mu_{P M 10}^{Y O K}>\mu_{P M 10}^{V A R}\right)}$ Ortalamaların Eşitliğine Dair t-testi

\begin{tabular}{|c|c|c|c|c|c|c|c|}
\hline \multirow{2}{*}{ : } & \multirow[b]{2}{*}{ 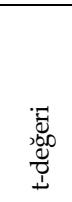 } & \multirow{2}{*}{ 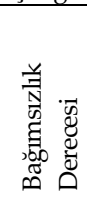 } & \multirow{2}{*}{ 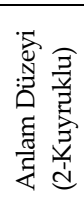 } & \multirow{2}{*}{ 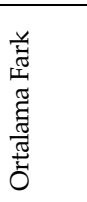 } & \multirow[b]{2}{*}{ 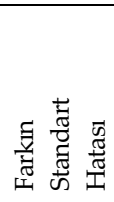 } & \multicolumn{2}{|c|}{$\begin{array}{c}\text { Farkın \%95 Güven Ara- } \\
\text { lığ1 } \\
\end{array}$} \\
\hline & & & & & & Alt & Üst \\
\hline I IBB & 5,182 & 24,670 & 0,000 & 8,351 & 1,612 & 5,030 & 11,673 \\
\hline İBB & 4,633 & 12,182 & 0,000 & 10,680 & 1,670 & 7,277 & 14,082 \\
\hline & 7,287 & 27,857 & 0,001 & 10,257 & 2,214 & 5,440 & 15,072 \\
\hline İBB & 0,977 & 13,341 & 0,011 & 6,898 & 2,353 & 1,860 & 11,930 \\
\hline a İBB & 5,182 & 24,670 & 0,000 & 11,866 & 1,628 & 8,530 & 15,203 \\
\hline izR & 4,633 & 12,182 & 0,197 & 3,014 & 2,197 & $-1,804$ & 7,832 \\
\hline & 7,287 & 27,857 & 0,346 & 2,685 & 2,750 & $-3,240$ & 8,610 \\
\hline İBB & 0,977 & 13,341 & 0,592 & 1,808 & 3,263 & $-5,442$ & 9,057 \\
\hline
\end{tabular}


Tüm istasyonlarda çarpıklık ve basıklık (skewness and kurtosis) değerleri incelendiğinde, bu değerlerin -3 ile +3 arasında olduğu, dolayısıyla veri dağılımlarının normal olduğu tespit edilmiştir. Verilerin normal dağılımı baz alınıp her istasyonda Bağımsız Örneklem t-testi uygulanmıştır (Tablo 4). Bağımsız Örneklem t-testi tüm istasyonlarda SÇYU günlerdeki PM10 konsantrasyonları ile, SÇYO günlerdeki PM10 konsantrasyonları arasında bir fark olup olmadığını test etmek amaciyla uygulanmış ve her istasyonda SÇYU günlerde PM10 konsantrasyonların ortalamalarında azalma olduğunu ortaya koymuştur. T-testi sonuçlarına göre Alsancak İBB, Bayraklı IBB, Çiğli İBB, Gaziemir, Karşıyaka İBB istasyonlarında istatistiksel olarak anlamlı bir fark tespit edilmiştir. Şirinyer İBB, Bornova IBBB ve Güzelyalı İBB istasyonlarında ise istatistiksel olarak anlamlı bir fark bulunmamıştır.

\section{5-2020 Yıllan Arasında Hava Kalitesi Değişiminin Değerlendirilmesi}

Bu bölümde, araştırmaya konu olan 8 takvim gününe ait hava kalitesi ölçüm değerleri 2015-2020 yılları arasında hem istasyon bazında hem de her yılın 2020 yılı ile arasındaki farklılık bazında ele alınmıştır. Veri setine ait betimleyici istatistikler Tablo 5'te verilmiştir. Betimleyici istatistikler incelendiğinde Alsancak IBBB ve Güzelyalı IBB istasyonları haricinde en yüksek ortalama değerlerinin 2018 yılında ölçüldüğü görülmektedir. 2019 yılında Gaziemir istasyonu hariç her istasyonun 3 günlük verisinin olmadığı görülmekte, dolayısıyla 2019 ortalama değerlerinin doğru sonuçlar vermediği düşünülmektedir. 2019 değerleri gözlem dışı bırakıldığında Bayraklı İBB, Karşıyaka İBB, Şirinyer İB ve Çiğli IBB istasyonlarında en düşük ölçülen PM10 ortalama değerinin 2020'de ölçüldüğü görülmektedir.

Ylllı veriler analiz edilirken hangi istasyonlarda istatistiksel olarak anlamlı bir farkın olduğunu tespit etmek amaciyla Friedman testi uygulanmıştır, testin sonuçları Tablo 6'da verilmiştir. Friedman testine göre anlamlı bir farkın tespit edildiği istasyonlar; Alsancak İBB ( $p<.05)$, Gaziemir $(\mathrm{p}<.05)$, Şirinyer İBB $(p<.05)$ ve Bornova İBB ( $p<.05)$ istasyonlarıdır. Sokağa çıma yasağının uygulandığ 2020 yılı ile tam olarak hangi yıl arasında, hangi istasyonlarda istatistiksel olarak anlamlı bir farkın olduğunu tespit etmek amaciyla Wilcoxon testi uygulanmıştır (Tablo 7). Wilconson Test sonuçlarına göre Güzelyalı IBB istasyonu hariç her istasyonda 2020 yılı PM10 konsantrasyonlarının 2018 yılından düşük ölçüldüğü görülmektedir. 2020-2015 yılları arasındaki ilişki incelendiğinde Gaziemir, Güzelyalı İBB ve Bornova İBB istasyonlarında 2020 yılında uygulanan sokağa çıkma kısıtlamasına rağmen 2015 yılında ölçülen PM10 konsantrasyonlarının daha düşük ölçüldüğü görülmektedir. Bu da 
2015'ten günümüze hava kalitesinin kentleşmeden olumsuz anlamda etkilendiğini ve hava kirliliğinin arttğını göstermektedir.

Tablo 5. 2015-2020 arası yıllık PM10 $\left(\mu \mathrm{g} / \mathrm{m}^{3}\right)$ ölçümlerin betimleyici istatistikleri

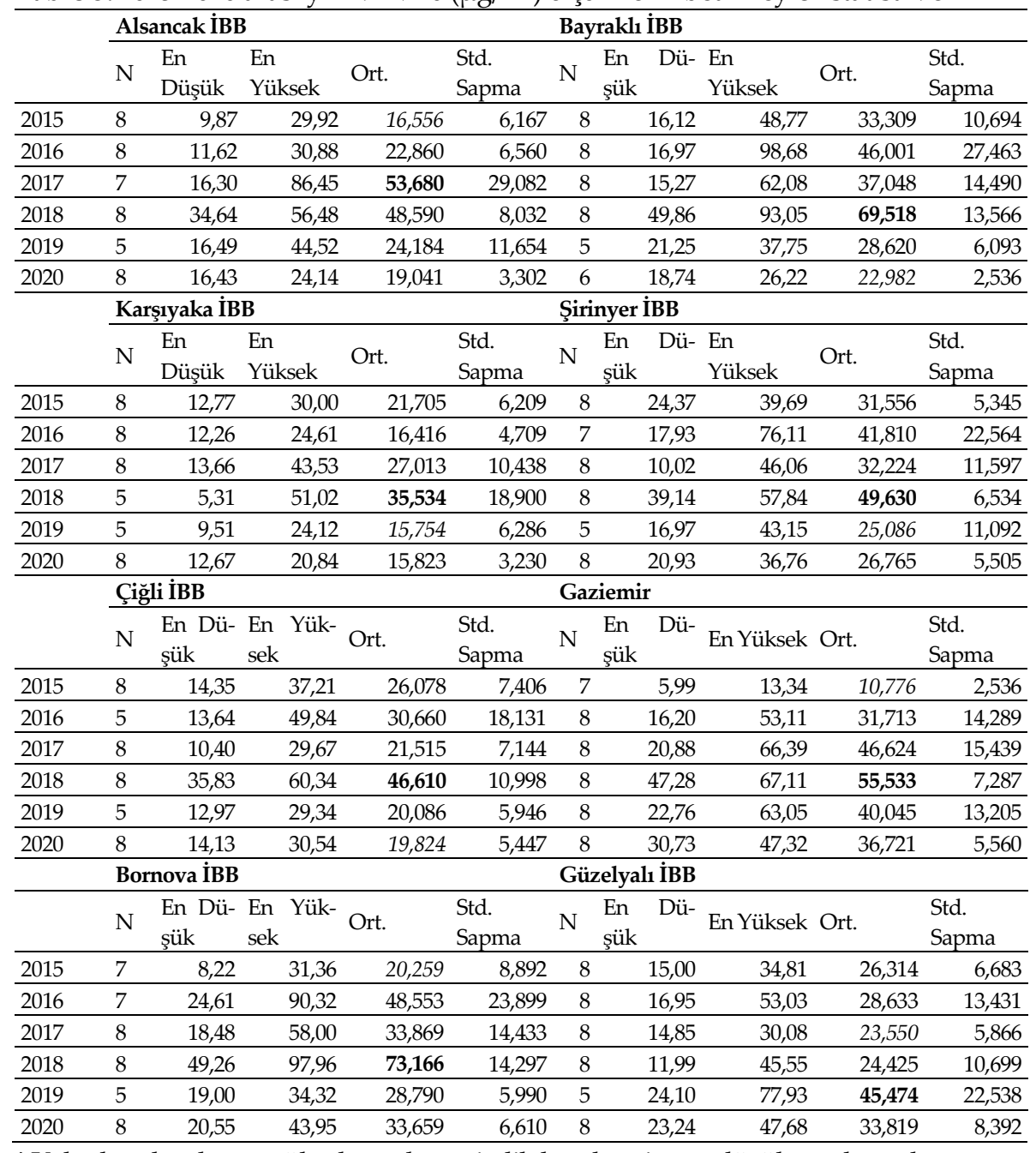

* Kalın karakterler en yüksek ortalama, italik karakter ise en düşük ortalamadır. 
Tablo 6. Friedman testi sonuçları $\left(\mathrm{H}_{0}: \mu_{P M 10}^{2015}=\mu_{P M 10}^{2016}=\mu_{P M 10}^{2017}=\mu_{P M 10}^{2018}=\mu_{P M 10}^{2019}=\right.$ $\mu_{P M 10}^{2020} \mathrm{H}_{1}$ : Eşitsizlik)

\begin{tabular}{|c|c|c|c|c|c|c|c|}
\hline \multicolumn{2}{|c|}{ Alsancak İBB } & \multicolumn{2}{|c|}{ Bayraklı İBB } & \multicolumn{2}{|c|}{ Çiğli İBB } & \multicolumn{2}{|c|}{ Gaziemir } \\
\hline $\mathrm{N}$ & 5 & $\mathrm{~N}$ & 3 & $\mathrm{~N}$ & 4 & $\mathrm{~N}$ & 7 \\
\hline Ki-Kare & 16,086 & Ki-Kare & 10,619 & Ki-Kare & 10,571 & Ki-Kare & 24,878 \\
\hline \multicolumn{8}{|l|}{ Bağımsızlı } \\
\hline $\mathrm{k}$ & & Bağımsızlık & & Bağımsızlık & & Bağımsızlık & \\
\hline Derecesi & 5 & Derecesi & 5 & Derecesi & 5 & Derecesi & 5 \\
\hline Anlamlılık ${ }^{*}$ & 0,007 & Anlamlılık ${ }^{*}$ & 0,059 & Anlamlılık ${ }^{*}$ & 0,061 & Anlamlılik ${ }^{*}$ & 0,000 \\
\hline \multicolumn{2}{|c|}{ Karşıyaka İBB } & \multicolumn{2}{|c|}{ Şirinyer IBB } & \multicolumn{2}{|c|}{ Bornova İBB } & \multicolumn{2}{|c|}{ Güzelyalı İBB } \\
\hline $\mathrm{N}$ & 5 & $\mathrm{~N}$ & 4 & $\mathrm{~N}$ & 4 & $\mathrm{~N}$ & 5 \\
\hline Ki-Kare & 6,714 & Ki-Kare & 11,429 & Ki-Kare & 14 & Ki-Kare & 6,143 \\
\hline Bağımsızlı & & Bağımsızlık & & Bağımsızlık & & Bağımsızlık & \\
\hline k Derecesi & 5 & Derecesi & 5 & Derecesi & 5 & Derecesi & 5 \\
\hline Anlamlllık & 0,243 & Anlamlllık & 0,044 & Anlamllik ${ }^{*}$ & 0,016 & Anlamlllık ${ }^{*}$ & 0,293 \\
\hline
\end{tabular}

* Kalın karakterlerde anlamlılık \%5 altı, italik karakterlerde ise \%10 altıdır.

Tablo 7. Wilcoxon testi sonuçları $\left(\mathrm{H}_{0}: \mu_{P M 10}^{2020}=\mu_{P M 10}^{201 X} \mathrm{H}_{1}: \mu_{P M 10}^{Y O K} \neq \mu_{P M 10}^{V A R}\right)$

\begin{tabular}{|c|c|c|c|c|c|c|}
\hline & & 2020-2015 & 2020-2016 & 2020-2017 & 2020-2018 & 2020-2019 \\
\hline \multirow[t]{2}{*}{ Alsancak İBB } & Z & $-0,840$ & $-1,540$ & $-2,197$ & $-2,521$ & $-0,135$ \\
\hline & Anlamlılık (2-Kuyruklu)* & 0,401 & 0,123 & 0,028 & 0,012 & 0,893 \\
\hline \multirow[t]{2}{*}{ Bayraklı İBB } & $\mathrm{Z}$ & $-1,992$ & $-2,201$ & $-1,572$ & $-2,201$ & $-1,069$ \\
\hline & Anlamlılık (2-Kuyruklu)* & 0,046 & 0,028 & 0,116 & 0,028 & 0,285 \\
\hline \multirow[t]{2}{*}{ Ciğli İBB } & Z & $-1,820$ & $-0,944$ & $-0,280$ & $-2,521$ & $-0,405$ \\
\hline & Anlamlilık (2-Kuyruklu)* & 0,069 & 0,345 & 0,779 & 0,012 & 0,686 \\
\hline \multirow[t]{2}{*}{ Gaziemir } & $\mathrm{Z}$ & $-2,366$ & $-0,980$ & $-1,540$ & $-2,521$ & $-0,560$ \\
\hline & Anlamlılık (2-Kuyruklu)* & 0,018 & 0,327 & 0,123 & 0,012 & 0,575 \\
\hline \multirow[t]{2}{*}{ Karşıyaka BB } & Z & $-1,820$ & $-0,420$ & $-2,100$ & $-1,753$ & $-0,674$ \\
\hline & Anlamlılık (2-Kuyruklu)* & 0,069 & 0,674 & 0,036 & 0,080 & 0,500 \\
\hline \multirow[t]{2}{*}{ Şirinyer İBB } & $\mathrm{Z}$ & $-1,540$ & $-1,521$ & $-1,400$ & $-2,521$ & $-0,674$ \\
\hline & Anlamlılık (2-Kuyruklu)* & 0,123 & 0,128 & 0,161 & 0,012 & 0,500 \\
\hline \multirow[t]{2}{*}{ Bornova İBB } & $\mathrm{Z}$ & $-2,197$ & $-1,690$ & $-0,140$ & $-2,521$ & $-1,753$ \\
\hline & Anlamlılık (2-Kuyruklu) ${ }^{*}$ & 0,028 & 0,091 & 0,889 & 0,012 & 0,080 \\
\hline \multirow[t]{2}{*}{ Güzelyalı İBB } & $\mathrm{Z}$ & $-1,820$ & $-0,840$ & $-2,380$ & $-2,521$ & $-0,674$ \\
\hline & Anlamlilık (2-Kuyruklu)* & 0,069 & 0,401 & 0,017 & 0,012 & 0,500 \\
\hline
\end{tabular}

* Kalın karakterlerde anlamlılık \%5 altı, italik karakterlerde ise $\% 10$ altıdır. Kırmızı karakterler negatif anlamda farklılık belirtirken, siyah karakterler pozitif anlamda farklılık belirtmektedir.

\section{Tartışma ve Sonuç}

Covid-19 Pandemisi önlemleri kapsamında sokağa çıkma kısıtlamasının esnetilmeden uygulandığı ilk dönemde (11-12, 18-19, 23-26 Nisan 2020), İzmir merkez kentinin hava kalitesi ölçüm istasyonlarından elde edilen verilere göre, kısıtlamalar hava kalitesini olumlu yönde etkilemiştir. İstatistiksel olarak incelendiğinde anlamlı bir farkın Alsancak İBB, Bayraklı İBB, Çiğli İBB, Gaziemir ve Karşıyaka İBB istasyonlarından alınan verilerde olduğu tespit edilmiştir. Bornova, Güzelyalı ve Şirinyer istasyonlarında istatistiksel olarak 
anlamlı bir fark gözlemlenmemiştir. Bu sonuç söz konusu istasyonların konumları incelendiğinde yorumlanabilir niteliktedir. Güzelyalı istasyonunun körfezden, Bornova ve Şirinyer istasyonlarının tarım ve orman alanlarından rüzgar alıyor olması temiz hava akımının sağlandığı varsayımını doğurmaktadır. Buna ek olarak her üç istasyonun da merkez kentin çeperinde, kent içi trafik yoğunluğunun görece azaldığı bölgede yer aldığı görülmektedir. Özellikle güneyde Güzelyalı İBB ve güneydoğuda Şirinyer İBB istasyonlarının yakın çevreleri mahalle bazında nüfus yoğunluğunun en yüksek olduğu konut bölgeleridir. Bornova İBB istasyonu yakın çevresinin görece gözenekli yapısı ve tarım, orman ve doğal alanlarla çevrelenmesi anlamlı farklılığın ortaya çımaması sonucunu açıklasa da bu istasyonlarda da sokağa çıkma kısıtlamasının uygulandığı günlerin hava kalitesinin diğer günlerden daha iyi olduğu görülmektedir. Dolayısıyla günlük insan hareketliliğinin (yoğun trafik, endüstriyel emisyonlar), İzmir özelinde hava kirliliğini arttırdığı çalışma kapsaminda tespit edilmiştir.

Yıllık düzeyde elde edilen sonuçlar incelendiğinde öncelikle 2019 yılında yeterli veri olmadığ için 2020 ile karşılaştırmasının doğru sonuçlar vermediği düşünülmektedir. Fakat 2018 ile 2020 yılları karşılaştırıldığında tüm istasyonlarda hava kalitesinin 2020 yılında 2018' e göre iyileşmiş olduğu -PM10 konsantrasyonlarının azaldığı- tespit edilmiştir. Genel olarak yıllık verilerin betimleyici istatistiklerine bakıldığında 2018' de geçmiş yıllara göre PM10 ölçümlerinin zirve yaptığı görülmektedir. 2019'daki veri eksikliği ve 2020'de aynı tarihlerde sokağa çıkma kısıtlamasının uygulanmış olması durumu 2015 'ten günümüze hava kalitesinin nasıl değiştiği konusunda yorum yapmamızı engellese de 2015 yılından 2018 yılına hava kalitesinin giderek kötüleştiği açıkça gözlemlenmektedir. Analizler genel olarak ulaşım, taşımacılık ve fonksiyon karakteristiğinin hava kalitesine etki ettiğini ve özellikle trafik yoğunluğu ile sanayi üretiminin hava kirliliğini arttırdığını tespit etmiştir.

İzmir merkez kentinin planlama çalışmaları yapılırken bu sonuçlar göz önünde bulundurulmalı ve hava kirliliğini önleyici politikalar/stratejiler geliştirilmelidir. Üstelik İzmir'in sadece bu çalışmaya konu merkezinin yoğun kentsel kullanımları hava kirliliğine sebep olmamakta; çeperi de saçaklı yapısından dolayı hava kirliliğini arttırmaktadır. Kuzeyde Menemen'e doğru konut ve sanayi amaçlı saçaklanmalar, güneyde Güzelbahçe ile Seferihisar arasında kalan çeper bölgenin konut amaçlı kısmi yapılaşması ve Gaziemir ile Torbalı arasında kalan alanının yine konut, sanayi ve depolama amaçlı olarak gelişmesi kentin üç ana eksende saçaklandığını göstermektedir. Bu sebeple İzmir'in giderek artan yoğun kentleşmesi ve bu durumun yarattığı kirliliğe 
karşı 1/25.000 ölçekli İzmir Büyükşehir Bütünü Çevre Düzeni Planı'nda merkez kentin yoğunlaşmasını ve saçaklanmasını, orman alanları, ağaçlandırılacak alanlar, doğal ve ağaçlık karakteri korunacak alanlar, baraj ve koruma alanları gibi doğal eşiklerle sınırlandıran 'Yeşil Kuşak Alanı' tanımlanmış ve 'İzmir Yeşil Altyapı Stratejisi' geliştirilmiştir (IBB, 2012). ${ }^{11}$

'İzmir Yeşil Altyapı Stratejisi' ise su ve kara sistemlerinin etkileşimini, doğal-yarı doğal-kentsel alanlardaki geçişliliği, yapılan tüm uygulamalarda yenilikçi doğa-esaslı çözümlerden yararlanmayı hedeflemiştir. Merkez kentte özellikle İzmir Körfezi'ni besleyen kent içi akarsu sistemlerinin kentin doğal yaşam koridorları olarak tanımlanmasını ve yeşil kuşak ile ilişkili bir yeşil ağ sisteminin yeniden kurgulanmasını gündeme getirmiştir (İBB, 2017). Bu kapsamda yeşil alanlar, su alanları, koridorlar ve bağlantılar ile yapılar, atıl ve onarılacak alanlar alt başlıkları altında stratejiler belirlenmiştir. Bu önemli başlangıç Avrupa Birliği'nin Ufuk 2020 programı kapsaminda desteklenen Urban GreenUp Projesi ile devam etmektedir (Urban GreenUp, 2020). Benzer uygulama projelerinin geliştirilmesi, hava kirliliğini de azaltacağ iç̧in önemlidir.

Bu üst ölçekli planlama kararlarına ek olarak yürüme mesafesinde tasarlanan mahalleler, yürüme ve bisiklet rotaları, toplu taşıma bağlantı noktaları, yenilenebilir ve yeşil teknoloji kapsamında değerlendirilen elektrikli araçlar, güneş enerji sistemleri gibi düşük karbon projelerin yayginlaştırılması da gerekmektedir (Gündel ve Velibeyoğlu, 2020). İç Körfez, kıyılar ve kent teraslarını ele alan 'İzmir Deniz Projesi', kıyı erişimini sağlama, açık alanlar yaratma, kesintisiz yaya ve bisiklet yolları oluşturma, doğa ve teknolojiyi birleştiren kent mobilyaları tasarlama gibi farklı birçok uygulamalarıyla dolaylı olarak hava kalitesini hedefleyen önemli bir proje olsa da hava kirliliğini kontrol amaçlı planlama ve tasarım projeleri geliştirilmelidir.

2016 yılında İzmir için Temiz Hava Eylem Planı (İzmir Valiliği, 2020) hazırlanmıştır. Hazırlanan planda evsel ısınma kaynaklı kirliliğin azaltılması, sanayi kaynaklı kirliliğin azaltılması ve trafik kaynaklı kirliliğin azaltılması başlıkları altında 2016 ile 2019 yılları arasında gerçekleştirilmesi hedeflenen kararlar alınmıştır. Söz konusu plan 2019 yılında revize edilmiştir. Ancak, hava kalitesine yönelik hazırlanan eylem planları, kent formundan yeşil kuşaklarına, kirletici sanayinin yer seçiminden yeni konut alanlarına veya kent

\footnotetext{
11 'Yeşil Kuşak Alanı' olarak 2007 yılı onaylı 1/25.000 ölçekli İzmir Kentsel Bölge Nazım İmar Planı ile tanımlanmıştır.
} 
hava koridorlarından sokak sürekliliklerine çeşitli mekansal planlama kararları ve tasarım projeleriyle bütünleştirilmelidir. Mekânsal kararlar içeren bir hava kirliliği kontrol planı yapılmadan sadece eylem planları hazırlamak, hava kirliliğini önleme ve önüne geçme konusunda yetersiz kalacaktır. Benzer bir şekilde üst ölçekli bölgesel planlardan mahalle, sokak veya park ölçeğindeki tasarım projelerine kadar mekansal kararlarda hava kirliliğini azaltıc önlemler ana bileşen olarak yer almalıdır. 


\section{Extended Abstract}

\section{The Effect of Curfews on the Air Quality of Cities, The Case of Izmir}

\author{
Neşe Aydın \\ ORCID: 0000-0002-1914-3381
}

\author{
Emine Yetişkul \\ ORCID: 0000-0003-0829-1562
}

This study was carried out to determine how the concentrations of some atmospheric pollutants in the Izmir metropolitan area changed on the days of curfews during Covid-19 Pandemic. After the first case was detected on March 11, 2020 in Turkey, governmental agencies introduced many protective measures and prohibitions to control the spread of this contiguous disease. Some of them were hour or day based curfews, change of classroom based education to online education, encouragement of flexible working hours and teleworking, and restrictions of inter and intra-city movement. In 'first fear' period after the detection of the first case, people did not take risks, keep away from all public activities and areas, and stopped movement. In addition, public and private institutions as well as firms slowed down their production activities and practiced remote or rotational work. All measures and prohibitions aimed to minimize the mobility and reduce face-to face interactions outside homes affected air quality directly or indirectly. To analyze effects of these changes in daily routines in pollutant levels before and after Covid-10 Pandemic, we used data collected by eight air quality measurement stations in İzmir. By comparing the daily data on a station basis, we captured air pollution caused by human activities, especially transportation and industrial production, which can further be used to develop strategies and policies for the prevention of air pollution in urban environment.

Analyzes were only based on the PM10 pollutant measured at each station due to data limitations for other pollutants. Within the scope of this study, concentration levels of the days when the curfew was imposed (April 11-12, 2020; April 18-19, 2020; April 23-26, 2020) were compared with that of the other days of April 2020 as well as other three months before and after April 2020. Besides, 
further analyses present how the air quality has changed on an annual basis from 2015 to 2020 and how the curfew affected the air quality. In urban areas, air quality varies according to both natural and anthropogenic sources such as forest fires or traffic, industry or domestic heating as well as atmospheric and meteorological variables and topographic characteristics of the region. In this study, data of each station were evaluated in itself as assuming that natural structure (topography, vegetation) and built environment characteristics (building heights, urban land use) around the stations did not change to a large extent in short-term. Besides, it was supposed that the atmospheric and meteorological characteristics were similar during the same days of the month or year.

To analyze the daily data of 2020, independent sample t-test was used. On the other hand, both the Friedman and Wilcoxon tests were applied to analyze the annual data between 2015 and 2020. Although each station presented difference in the PM10 concentration average when the curfew days were compared with that of other days in 2020, five out of eight stations (i.e., Alsancak IMM, Bayraklı IMM, Çiğli IMM, Gaziemir and Karşıyaka IMM stations) revealed statistically significant differences. On an annual basis, difference between 2018 and 2020 was statistically significant. In general, improvements in air quality in terms of PM10 concentrations were found during the curfew days, implying that our daily activities and mobility patterns in cities negatively affect the ambient air quality. The literature has revealed that low-density, automobile-dependent urban development (e.g., urban sprawl) increase air pollution, while mixed-land use, compact urban forms with shorter travel distances reduce air pollution (McCarty and Kaza, 2015; Cervero and Kockelman, 1997; Frank and Pivo, 1994). In this direction, strategies and policies could be developed to mitigate air pollution when planning our cities.

This study also presents findings related with urban development pattern of İzmir metropolitan area. Residential and industrial sprawl towards Menemen in the north, partial residential development in the periphery between Güzelbahçe and Seferihisar in the south, and development of the area between Gaziemir and Torbalı for residential, industrial and storage purposes show that the city has been sprawling in three main corridors. These developments pose risks against "The Green Belt" which borders the dense central city and its corridors, and aims to retain forests, undeveloped, natural or agricultural lands that surround urban areas and thereby provides air ventilation corridors to control air pollution according to İzmir Metropolitan Area master plan. 
On the other hand, the Clean Air Action Plan of İzmir (İzmir Valiliği, 2020) was prepared in 2016 for reducing pollution caused by domestic heating, industry and traffic; however, fallen behind to attain its targets in three years. Then it was revised in 2019. More importantly, the action plan failed to work in tandem with land-use decisions or project its strategies over spatial development. According to the results of this study, air quality action plans should strongly be associated with urban form, planning and land use decisions such as green belts, location of polluting industry, new residential areas, city air corridors, street continuities etc. Following this line, measures to mitigate air pollution should be the main component in spatial planning from regional scale to neighborhood and street level design projects. Planning should support low-carbon projects such as neighborhoods designed within walking distance, walking and cycling routes, public transportation transfer hubs, and electric vehicles (Gündel and Velibeyoğlu, 2020). Although the 'İzmir Sea Project', which deals with the İzmir Bay, coasts and city terraces, is an important project that indirectly targets air quality with many different applications such as improving coastal access, providing open spaces, creating uninterrupted pedestrian and bicycle paths, and designing urban furniture that combines nature and technology, planning and design projects should incorporate direct measures to control air pollution. Besides the scope of renewable and green technology, and solar energy systems should also be expanded to improve air quality.

\section{Kaynakça}

Alan M. Voorhees \& Associates, Ryckman, Edgerley, Tomlinson and Associates, \& United States. Environmental Protection Agency. Office of Air Programs. (1972). A Guide for Reducing Air Pollution Through Urban Planning: Prepared for the Office of Air Programs, the Environmental Protection Agency, December 1971. National Technical Information Service.

Arora, S., Bhaukhandi, K. D., \& Mishra, P. K. (2020). Coronavirus lockdown helped the environment to bounce back. Science of the Total Environment, 140573.

Bahukhandi, K., Agarwal, S., \& Singhal, S. (2020). Impact of lockdown Covid-19 pandemic on himalayan environment. International Journal of Environmental Analytical Chemistry, 1-15.

Bao, R., \& Zhang, A. (2020). Does lockdown reduce air pollution? Evidence from 44 cities in northern China. Science of the Total Environment, 731, 139052.

Baysan, C., \& Yavaş, S. P. (2020). Covıd-19 Ve Hava Kirliliği; Karantina Boyunca Ne Oldu?. ESTÜDAM Halk Sağh̆ğ Dergisi, 5, 35-46.

Bereitschaft, B., \& Debbage, K. (2013). Urban form, air pollution, and CO2 emissions in large US metropolitan areas. The Professional Geographer, 65(4), 612-635. 
Cervero, R., \& Kockelman, K. (1997). Travel demand and the 3Ds: Density, diversity, and design. Transportation research part D: Transport and environment, 2(3), 199219.

Clark, L. P., Millet, D. B., \& Marshall, J. D. (2011). Air quality and urban form in US urban areas: Evidence from regulatory monitors. Environmental Science $\mathcal{E}$ Techno$\log y, 45(16), 7028-7035$.

Collivignarelli, M. C., Abbà, A., Bertanza, G., Pedrazzani, R., Ricciardi, P., \& Miino, M. C. (2020). Lockdown for CoViD-2019 in Milan: What are the effects on air quality?. Science of the total environment, 732, 139280.

Copernicus. (2020, Şubat). Land Monitoring Service, Corine Land Cover. https://land.copernicus.eu/pan-european

Çevre ve Şehircilik Bakanlığı (2021, Ocak). Hava Kalitesi Bülteni, Kasım 2020. Çevresel Etki Değerlendirmesi, İzin ve Denetim Genel Müdürlüğü, Çevre ve Şehircilik Bakanlı̆̆, Ankara.

Dantas, G., Siciliano, B., França, B. B., da Silva, C. M., \& Arbilla, G. (2020). The impact of COVID-19 partial lockdown on the air quality of the city of Rio de Janeiro, Brazil. Science of the total environment, 729, 139085.

Doğan, F., Kitapçıŏlu, G. (2007). İzmir ilinde hava kirliliğinin yıllar itibariyle karşılaştırilmasi. Ege Tip Dergisi, 46(3), 129-133.

Elbir, T., Altıok, H., Seyfioğlu, R., Bayram, A., Ergün, P., Eren, T., Şimşir, S., Dumanoğlu, Y., Kara, M., Sayır, S. (2008). İzmir kent merkezindeki ana arterlerde hava kïrleticilerïn zamansal değişimlerinin incelenmesi. Hava Kirliliği ve Kontrolü Ulusal Sempozyumu, 22-25 Ekim 2008, Hatay.

Ewing, R., and F. Rong. (2008). The impact of urban form on U.S. residential energy use. Housing Policy Debate, 19(1), 1-30.

Frank, L.D., Pivo, G. (1994). Impacts of mixed use and density on utilization of three modes of travel: single-occupant vehicle, transit, and walking. Transportation research record, 1466, 44-52.

Grimm, N.B., S.H. Faeth, N.E. Golubiewski, C.L Redman, J. Wu, X. Bai, Briggs, J.M.. (2008). Global change and the ecology of cities. Science. 319, 756-760.

Gündel, H., Velibeyoğlu, K. (2020), Düşük karbon mahalle: Yürüme ve bisiklet öncelikli kentsel tasarım. Meltem İzmir Akdeniz Akademisi Dergisi, 8, 5-21.

Hadley, M.B., Baumgartner, J., Vedanthan, R., (2018). Developing a clinical approach to air pollution and cardiovascular health. Circulation Journal, 137(7), 725-742.

İçişleri Bakanlığı. (2020, Şubat). https://www.icisleri.gov.tr/duyuru1004. https://www.icisleri.gov.tr/17-19-nisan-tarihleri-arasinda-30-buyuksehir-ve-zonguldak-il-sinirlari-icerisinde-sokaga-cikma-yasagi. https://www.icisleri.gov.tr/30-buyuksehir-ve-zonguldak-ilinde-23-24-25-26-nisan-tarihlerinde-uygulanacak-sokaga-cikma-kisitlamasi.

İzmir Valiliği. (2020, Şubat). Çevre ve Şehircilik İl Müdürlüğü, Temiz Hava Eylem Planı https://izmir.csb.gov.tr/temiz-hava-eylem-plani-i-6545 
Kalaiarasan, G., Balakrishnan, R.J., Sethunath, N.S., Manoharan, S. (2018). Source apportionment studies on particulate matter (PM10 and PM2.5) in ambient air of urban Mangalore, India. Journal of Environmental Management, 217, 815-824.

Kemp, D. D. (2004). Exploring environmental issues: An integrated approach. Routledge.

Kumari, P., \& Toshniwal, D. (2020). Impact of lockdown measures during COVID-19 on air quality-A case study of India. International Journal of Environmental Health Research, 1-8.

Lu, C., Liu, Y. (2016). Effects of China's urban form on urban air quality. Urban Studies, $53,2607-2623$.

Meteoroloji 2. Bölge Müdürlüğü (2021, Haziran) https://izmir.mgm.gov.tr/

McCarty, J., \& Kaza, N. (2015). Urban form and air quality in the United States. Landscape and Urban Planning, 139, 168-179.

Nakada, L. Y. K., \& Urban, R. C. (2020). COVID-19 pandemic: Impacts on the air quality during the partial lockdown in São Paulo state, Brazil. Science of the Total Environment, 730, 139087.

Rodríguez, M. C., Dupont-Courtade, L., \& Oueslati, W. (2016). Air pollution and urban structure linkages: Evidence from European cities. Renewable and Sustainable Energy Reviews, 53, 1-9.

Rydell, C.P., Schwarz, G. (1968). Air pollution and urban form: A review of current literature. Journal of the American Institute of Planners, 34(2), 115-120.

Sağlık Bakanlığı. (2020, Şubat). https://www.saglik.gov.tr/TR,64383/koronavirus-alacagimiz-tedbirlerden-guclu-degildir.html

Singh, J., \& Tyagi, B. (2021). Transformation of Air Quality over a Coastal Tropical Station Chennai during COVID-19 Lockdown in India. Aerosol and Air Quality Research, 21.

Stone Jr, B., Mednick, A. C., Holloway, T., \& Spak, S. N. (2007). Is compact growth good for air quality?. Journal of the American Planning Association, 73(4), 404-418.

Tabachnick, B.G., Fidell, L.S. (2013). Using Multivariate Statistics, 6th Edition, Pearson.

Urban GreenUp. (2020, Ocak). https://www.urbangreenup.eu/

Weng, Q. (2003). Fractal analysis of satellite-detected urban heat island effect. Photogrammetric engineering $\mathcal{E}$ remote sensing, 69(5), 555-566.

World Health Organization (WHO) (2021, Ocak). Rolling updates on coronavirus disease (Covid-19). https://www.who.int/emergencies/diseases/novel-coronavirus2019/events-as-they-happen 454.

Yatkın, S., Bayram, A. (2007). İzmir havasında Partikül madde kirliliği: Ölçüm ve değerlendïrme. DEÜ Mühendislik FakültesïFen ve Mühendislik Dergisi, 9(2), 15-27.

Zhou, Y., Levy, J.I. (2008). The impact of urban street canyons on population exposureto traffic-related primary pollutants. Atmospheric Environment, 42, 3087-3098. 